(C) 2014

\title{
RADIOCARBON DATING OF ANCIENT POTTERY
}

M.A. Kulkova, candidate of geological and mineralogical sciences, associate professor of the Department of Geology and geoecology

Herzen State University, St.Petersburg (Russia)

Annotation: The radiocarbon dating of ancient ceramics is an important aspect of investigations both the radiocarbon analysis and the archaeology. The time of a making and using of pottery corresponds directly with the time of the ancient people existing. In spite on that fact that the pottery radiocarbon dating has many problems because of different sources of carbon inside pottery, there is the possibility for correct radiocarbon dating with using both the AMS technique and the conventional technique. The main problem of pottery radiocarbon dating is how to separate intrinsic pottery carbon from older "geological" carbon and younger carbon absorbed by pottery pores during burial. The examination of basic stages of pottery making and using gives the possibility to assess the main sources of carbon entrance to a ceramic vessel. The compositional analysis of clay and temper that had been used for pottery making should be considered. The method of the temperature control during combustion should be applied in process of the radiocarbon dating. It is very important to supply the careful chemical pretreatment of ceramics with aim to remove the older and younger contaminations. The comparison of pottery dates obtained with the relative dating according to pottery typology should use for control.

The other problem of the radiocarbon dating of pottery is the reservoir effect if the freshwater and the seawater fish or seafood were used in a cooking process. If the clay has the high carbonate concentration or shells inside pot-sherds the determination of $\delta^{13} \mathrm{C}$ should be done after carbonate removing. The careful chemical pretreatment of ceramics must guarantee the removing of humic acids forming after burial of pot-sherds and as well as in result of food cooking. The examination of $\delta^{13} \mathrm{C}$ should be provided for organics from pot-sherds. The correction of radiocarbon age can be realized. If it is possible the total content of carbon should determine in pot-sherds as well. In article the examples of radiocarbon dating of pottery organics from early Neolithic sites of Eastern Europe was considered.

Keywords: Neolithic; radiocarbon dating of pottery; reservoir effect; conventional dating; AMS; pottery technology.

\section{УДК902 \\ КОМПЛЕКС ВЕРХНЕВОЛЖСКОЙ КЕРАМИКИ РАННЕНЕОЛИТИЧЕСКОГО СЛОЯ СТОЯНКИ ЗАМОСТЬЕ 2: ТИПОЛОГИЧЕСКИЙ СОСТАВ И ХРОНОЛОГИЧЕСКИЕ РАМКИ (C) 2014}

B.M. Лозовский, кандидат исторических наук, старший научный сотрудник отдела палеолита

$\boldsymbol{O}$.B. Лозовская, кандидат исторических наук, научный сотрудник экспериментально-трасологической лаборатории

Институт Материальной культуры РАН, С-Петербург (Россия),

Сергиево-Посадский музей-заповедник, Сергиев-Посад (Россия)

Г.И. Зайцева, кандидат химических наук, старший научный сотрудник лаборатории

археологической технологии

Институт Материальной культуры РАН, С-Петербург (Россия)

Г. Поснерт, профессор, доктор, «Лаборатория Ангстром»,

Университет г. Упсала, Упсала (Швеичя)

M.A. Кулькова, кандидат геолого-минералогических наук, доцент кафедры геологии и геоэкологии Российский государственный педагогический университет им.А.И.Гериена Санкт-Петербург (Россия)

Аннотация: В работе дается характеристика комплекса ранненеолитической верхневолжской керамики стоянки Замостье 2. В результате проведенного анализа выяснилось, что подавляющее большинство фрагментов, найденных в ходе раскопок памятника, принадлежат первому этапу развития верхневолжской культуры - это керамика без орнамента и с тычково-накольчатой орнаментацией. Проведенное обширное радиоуглеродное датирование по разным видам материалов позволило определить время бытования верхневолжской культуры в рамках 6850 - 6200 л.н. Тем не менее небольшая серия дат, полученная по нагару на фрагментах керамики, демонстрирует более древний возраст по сравнению с основным массивом дат. Природа подобного удревнения в настоящий момент не совсем ясна.

Ключевые слова: ранний неолит, верхневолжская культура, Волго-Окское междуречье, радиоуглеродное датирование.

Стоянка Замостье 2 (Сергиево-Посадский $\mathrm{p}-\mathrm{H}$ Московской области) занимает одно из ведущих мест в изучении мезолита и раннего неолита Волго-Окского междуречья не только в связи с превосходной сохранностью изделий из органических материалов, но и благодаря необычайно большому количеству других культурных остатков, найденных в ходе исследований памятника $[1,2,3]$. Одно из ведущих мест в этом списке принадлежит обширной коллекции верхневолжской керамики, происходящей из ранненеолитического культурного слоя памятника. Первая публикация комплекса верхневолжской керамики базировалась в основном на материалах раскопок 1989-1991 гг. [2] без учета исследований 1995-2000 гг. Отдельное исследование технологии изготовления было проведено для комплекса керамики без орнамента [4]. В настоящей работе нами приводятся данные по всему объему керамического материала, который был получен в ходе раскопок стоянки в 1989-1991 гг. и в 1995-2000 гг., а также происходящий из сборов в русле реки Дубны, которая размывает культурные слои памятника.

Вся коллекция ранненеолитической керамики стоянки Замостье 2 была проанализирована согласно типологии, предложенной Д.А. Крайновым и Е.Л. Костылевой [5, с. 169; $6 ; 7 ; 8]$. В результате подтвердилось, что на древней стоянке преобладают два основных типа керамики: неорнаментированная керамика и керамика с тычково-накольчатой орнаментацией [2], которые принято считать наиболее архаичными в верхневолжской культуре. Более того, находки керамики с оттисками короткозубчатого 
штампа и длинного гребенчатого штампа, которые традиционно датируются более поздним временем [6,7], количественно уступают первой группе на порядок.

Всего на данный момент насчитывается 18248 фрагментов верхневолжской керамики, из них 5764 (31,6\% от всей керамики) - фрагменты без орнамента. Остальные 12484 фрагмента могут быть отнесены к следующим орнаментальным группам: керамика с тычково-накольчатым орнаментом; керамика с орнаментом «отступающая лопаточка»; керамика с оттисками короткозубчатого штампа; керамика с прочерченным орнаментом; керамика с оттисками штампа «длинная гребенка»; керамика с округлыми оттисками. Внутри этих основных орнаментальных групп присутствует большое количество фрагментов с комбинированным орнаментом, например, короткозубчатый штамп в сочетании с поясками разреженного накола. В этом случае фрагмент учитывался в группе с более поздним орнаментальным признаком. Очевидно, что подобные подсчеты по отдельным фрагментам достаточно условны, и наиболее адекватными следует признать подсчеты, проводимые по количеству найденных сосудов. К сожалению, на данный момент из-за большого массива материала подобный анализ провести практически невозможно.

Орнаментальная группа 1. Неорнаментированная керамика составила 5764 фрагмента, или 31,6\% всего массива керамики. 98\% этого количества составляют фрагменты стенок сосудов (рис. 14: 1, 5, 7, 9-13; 15). Такая диспропорция вызвана тем, что, по всей видимости, на большинстве сосудов раннего периода верхневолжской культуры орнамент наносился в основном на верхнюю часть сосудов. Часть венчиков украшена пояском редких крупных белемнитных вдавлений (рис. 3: 5), во многих случаях непосредственно под краем нанесены сквозные отверстия. Форма венчиков округлая с прямым или слегка отогнутым внутрь профилем. Донца неорнаментированных сосудов, подобно донцам с накольчатым орнаментом, имеют как приостренные (рис. 7: 2), так и плоские формы.

Орнаментальная группа 2. Тычково-накольчатая керамика насчитывает 8298 фрагментов, или 45,47\% от всей керамики (рис. 1, 2, 4). Накольчатый орнамент представляет собой последовательную цепочку разреженных овальных, округлых, каплевидных или подтреугольных вдавлений по окружности сосуда, реже встречаются удлиненные или удлиненно-подтреугольные вдавления, единично встречается орнамент, выполненный из округлых ямчатых вдавлений (рис. 14: 3) К этой же орнаментальной группе примыкают фрагменты со смешаннылм накольчатым типом орнаментации, когда на одном фрагменте встречено два и более разных по оттиску накольчатых оттисков. Всего таких фрагментов найдено 142 шт., или $0,8 \%$ от всей керамики. В качестве видимой примеси отмечается широкое использование шамота. Наружная поверхность фрагментов часто заглажена или подлощена, на внутренней видны следы расчесов.

По характеру орнаментальных композиций можно выделить следующие орнаментальные мотивы: 1. Одинарные пояски. Орнамент представляет собой пояски ямок, оставленных одиночным штампом, с промежутками между поясками, достаточными, чтобы можно было провести еще один или более подобных поясков. Суммарно насчитывается 5532 фрагментов этой подгруппы. 2. Встречные пояски. Орнамент представляет собой двойные пояски наклоненных в противоположные стороны ямок, оставленных одиночным штампом (405 фрагментов). 3. Пересекающиеся пояски. Орнамент представляет собой пояски ямок одиночного штампа, в промежутках между которыми, под разными углами, проведены соединяющие их дополнительные пояски подобного орнамента. Таких фрагментов найдено 521 шт. 4. Сплошные пояски. Орнамент представляет собой пояски ямок оставленных одинарным Самарский научный вестник. 2014. № 3(8) штампом, без промежутков между поясками орнамента. Стороны наклона наколов в таком орнаменте непостоянны. Всего в коллекции их 464 шт. В редких случаях встречаются другие орнаментальные мотивы: зигзаг, треугольники, елочка и единично - орнамент в виде сетки. По-видимому, орнамент наносился в основном в верхней и придонной частях сосудов, несколько реже можно отметить отдельные пояски накольчатой орнаментации с отходящими под углом к ним рядами наколов в средней части сосудов.

Венчики, донца и фрагменты керамики с ремонтными отверстиями.

Всего венчиков с накольчатым орнаментом найдено 1058 фрагментов, из которых 549 шт. имеют орнамент по срезу венчика (рис. 1: 3, 9, 11; 2: 4, 5, 9) и 509 шт. без него. Размер и форма наколов на венчиках варьируется от крупных, удлиненных диагональных наколов, до мелких, расположенных почти перпендикулярно срезу венчика. Среди венчиков преобладают фрагменты с прямым профилем и прямым срезом и венчики с прямым срезом с легким наклоном внутрь сосуда, многочисленны также венчики с округлым срезом прямые или с легким отгибом наружу. Присутствуют и другие формы венчиков - прямые с отгибом наружу и срезом по внутреннему краю; приостренные с аналогичным срезом.

Донцев найдено 192 шт. (рис. 6; 7: 1), среди которых встречаются приостренные, округлые и плоские. Наиболее распространены плоские донца, имеющие иногда с внешней стороны слабую вогнутость. Орнамент, встреченный на донцах включает сходящиеся к центру линии из каплевидных или овальных наколов, концентрические круги, параллельные линии и бессистемное заполнение. Орнаментация приостренных донцев сосудов состоит из рядов параллельных линий наколов.

Фрагментов сосудов с отверстиями для починки найдено 115 шт. (рис. 1: 9; 2: 5). В нескольких случаях в отверстиях были зафиксированы остатки лыка.

Орнаментальная группа 3. Керамика с орнаментом «отступающая лопаточка», или «ложношнуровой» орнамент. Всего найдено 327 фрагментов, или 1,8\% этого типа от всей керамики. Орнамент представляет собой очень близко посаженные накольчатые отпечатки, выполненные в отступающей технике, напоминающие отпечаток шнура (рис. 14: 4, б).

Орнаментальные композиции представляют собой цельные или прерывистые пояски, проведенные в одном направлении (91 фрагмент), пересекающиеся пояски из цельных или прерывистых линий оттисков, проведенных в разных направлениях (176 фрагментов).

Венчики, донца. Венчиков с орнаментом «отступающая лопаточка» найдено 41 шт., из которых 18 шт. имеют орнамент по верху венчика и 23 шт. без такового. Донцев с этим типом орнаментации найдено всего 8 шт.

Совершенно уникальную находку представляет фрагмент округлого донца $(10 \times 6,5 \times 1 \mathrm{~cm})$ с орнаментом, нанесенным по внутренней и внешней стороне (рис. 11,12 ). На внутренней стороне фрагмента совершенно отчетливо читается схематическое изображение мужчины с поднятыми вверх руками, выполненное в технике отступающей лопаточки. Рисунок снаружи передает схематическое изображение солнца в виде центрального круга с отходящими от него в разные стороны пучками лучей - три группы по три луча сконцентрированы на одной стороне центрального круга, еще два луча поставлены отдельно, и третий пересекает один из пучков. Рисунок «солнца» и лучей выполнен пунктирным мелкозубчатым штампом. Внешняя область этого изображения оконтурена пояскам подтреугольно-овальных накольчатых вдавлений. К сожалению, находка была сделана в русле реки Дубны, и ее конкретный археологический контекст утерян.

Орнаментальная группа 4. Керамика с оттисками 
короткозубчатого штампа. Всего найден 1191 фрагмент, или $6,53 \%$ от всей керамики. Оттиски на короткозубчатого штампа на черепках удлиненные, сужающиеся к концам, иногда овальные, ногтевидные с 1-4 зубцами в зависимости от длины штампа (рис. 3: 2). Комбинирование орнаментального штампа «короткая гребенка» и накольчатых оттисков найдено у 588 фрагментов, что составляет $3,22 \%$ всей керамики. В основном это встречный орнамент из пояска (или поясков) гребенчатого штампа и пояска из наколов (рис. 3: 1,3-6). В подобной манере украшен найденный на памятнике развал сосуда (рис. 8,9 ). Очевидно, что пояски накольчатой орнаментации служили разделителями поясков «гребенчатого штампа». Другой вариант комбинированного орнамента представлен фрагментами с оттисками короткозубчатого штампа, накольчатым орнаментом и оттисками, нанесенными в технике «отступающая лопаточка». Всего найден 71 фрагмент, что составляет $0,39 \%$ всей орнаментированной керамики. Зачастую оттиски короткозубчатого штампа, наносившиеся на поверхность сосуда в отступающей манере в дальнейшем переходили в отпечатки, называемые «отступающая лопаточка». Таких фрагментов найдено 26 фрагментов, или $0,14 \%$ от всей керамики.

Орнаментальные композиции, как и в случае с накольчатым типом орнамента, организованы в виде поясков: 1. Орнамент из ординарных поясков, выполненных короткозубчатым штампов, с промежутками между поясками, достаточными, чтобы можно было провести еще один или более подобных поясков. Таких фрагментов было найдено 620 шт. 2. Орнамент в виде встречных поясков из наклоненных в противоположные стороны коротких гребенчатых штампов (101 фрагмент). 3. Орнамент из пересекающихся поясков короткозубчатого штампа (92 фрагмента). 4. Сплошные пояски. Орнамент представляет собой пояски коротких гребенчатых штампов, без промежутков между поясками орнамента. Стороны наклона наколов в таком орнаменте непостоянны. Всего в коллекции насчитывается 80 шт. В некоторых случаях встречаются орнаментальные мотивы в виде елочки, одно- и многорядного зигзага или вписанных треугольников.

Венчики, донца и фрагменты керамики с отверстиями для ремонта.

Всего венчиков с оттисками короткозубчатого штампа найдено 242 шт. (рис. 3: 1, 3, 7), из которых 128 шт. имеют орнамент по верху венчика и 114 шт. без такового. Иногда по срезу венчика с внутренней стороны наносился орнамент. Форма венчиков округлая, плоская или отогнутая наружу. Донцев найдено 12 шт. Фрагментов керамики со сквозными отверстиями найдено 44 шт.

О форме сосудов этой группы керамки позволяет говорить найденный развал сосуда, полностью покрытый орнаментом из оттисков короткозубчатого штампа с разделительными поясками из наколов (рис. $8,9)$. Этот небольших размеров сосуд (высота $30,5 \mathrm{~cm}$, диаметр по венчику 24 см) имеет приостренное донце и плавное ребро перегиба в верхней части. Венчик слегка отогнут наружу и скошен изнутри. Сосуд украшен по всей поверхности горизонтальными поясками изогнутого короткозубчатого штампа, нанесенного в отступающей технике. Пояски штампа разделены через равные промежутки поясками овальных наколов (два ряда гребенки, один ряд наколов). По внутреннему срезу венчика также нанесен поясок из короткозубчатого штампа. В качестве примеси в тесте использовался шамот. Общая форма сосуда - закрытый остродонный «кубок» с перегибом в верхней части - характерна для этой группы керамики и может быть реконструирована по другим найденным фрагментам венчиков и средних частей сосудов (рис. 8).

Орнаментальная группа 5. Фрагментов керамики c прочерченным орнаментом найдено 73 фрагмента или $0,4 \%$ от всей керамики. Представляет собой прочерченные от руки линии. Орнаментальные мотивы перекликаются с мотивами орнамента, нанесенными штампом «длинная гребенка» и представлены сериями параллельных прочерченных линий, сеточного орнамента и вписанных треугольников. Сочетание прочерченного орнамента с накольчатым встречено на 58 фрагментах, что составляет $0,32 \%$ всей орнаментированной керамики. При этом пояски из накольчатого орнамента являются разделителями для поясков из прочерченных линий. Аналогичный прием мы встречаем на единственном реконструированном сосуде с прочерченным орнаментом.

Вызывает удивление тот факт, что при всей малочисленности ранненеолитической керамики с прочерченным орнаментом один из двух развалов сосудов, найденных в ходе раскопок на памятнике, украшен именно этим типом орнаментации (рис. 10). Этот сосуд отличается крупными размерами (высота 41 см, диаметр по венчику $30 \mathrm{~cm}$ ) и имеет закрытую остродонную форму с плавным ребром перегиба в верхней части. В качестве примеси в тесте были использованы шамот и песок. Венчик сосуда прямой со слегка округленным верхом, донце скруглено, орнамент покрывает всю поверхность сосуда. Орнамент представляет собой сочетание вписанных треугольников из наклонных рядов параллельных прочерченных линий в верхней и придонной частях сосуда и поясков из таких линий в средней части сосуда. Орнаментальные ряды из прочерченных линий разделены поясками ямок с пояском из овального накола под ними. Под венчиком поясок из ямок и накола перекрывает поясок короткозубчатого штампа. Верхняя часть сосуда была покрыта нагаром, под которым фиксируется слой красной краски (охры), который покрывал весь сосуд до половины его высоты. Подобный прием окраски сосуда красной краской нередко встречается на памятниках верхневолжской культуры [9].

Орнаментальная группа 6. В эту группу включена керамика с оттисками штампа «длинная гребенка» средней ширины. В чистом виде этот орнамент присутствует на 698 фрагментах (3,82\% от всей керамики) (рис. 5: 1, $7,9)$. Представляет собой прямоугольный или сужающийся к окончаниям штамп с многочисленными насечками (15-25 «зубцов»), зачастую такими глубокими, что при оттиске на сосуде остаются только отпечатки самих зубцов, а не всего штампа. Форма зубцов также изменяется на одном штампе от часто посаженных квадратных до редких, вытянутых, почти пунктирных. Зачастую оттиски штампа «длинная гребенка» сочетаются с накольчатым типом орнаментации. В этом случае пояски накольчатых оттисков являются разделителями между поясками, выполненными штампом «длинная гребенка». Подобных фрагментов керамики найдено 869, что составляет 4,76\% всей керамики (рис. 5: 2-6, 8). Другой вариант комбинирования орнаментального штампа «длинная гребенка» представлен фрагментами в сочетании с орнаментом из оттисков «короткой гребенки» и наколов. Всего найдено 53 таких фрагмента, что составляет 0,29\% всей керамики. Пояски накольчатых и короткогребенчатых оттисков попеременно или вместе являлись разграничителями между поясками штампа «длинная гребенка». Керамика этой группы имеет различные виды примесей, которые использовались при изготовлении теста сосуда - шамот, песок и дресва.

Орнамент, наносимый на сосуд. носил зональный характер и практически полностью покрывал всю его поверхность. Как правило, горизонтальные ряды гребенчатого орнамента разделяются на зоны с разделителем в виде овальных или округлых тычковых вдавлений, косо поставленного короткозубчатого штампа или горизонтального пояска гребенки. Из орнаментальных композиций можно выделить следующие варианты: 1. Одинарные пояски из наклонных поясков оттисков длинного гребенчатого штампа, промежутки

Самарский научный вестник. 2014. № 3(8) 
между которыми зачастую заполнялись накольчатыми оттисками. Фрагментов с подобным орнаментом было найдено 445 шт. 2. Пересекающиеся пояски из двойных поясков, наклоненных в противоположные стороны оттисков длинного гребенчатого штампа, кончики которых зачастую перекрещиваются. Всего найдено 117 фрагментов. Изредка встречаются орнаментальные композиции в виде елочки и «шагающей гребенки».

Венчики и донца. Всего венчиков с орнаментом из оттисков штампа «длинная гребенка» найдено 191 фрагмент (рис. 5: 1, 2), из которых 32 шт. имеют орнамент по срезу венчика и 86 шт. без такового. Срез венчиков, как правило, закругленный или плоский. Орнамент на венчиках наносился в большинстве случаев непосредственно от края сосуда - в основном, это наклонные параллельные ряды близко поставленного длиннозубчатого штампа. Донцев найденно найдено 48 шт., чаще всего округлой или приостренной формы.

Орнаментальная группа 7. Фрагментов керамики орнаментом из округлых оттисков найдено 10, или $0,05 \%$ от всей керамики. Представляет собой, вероятнее всего, отпечатки спилов птичьих костей. Найденные фрагменты покрыты рядами из этого орнамента, но определить характер орнаментальных композиций затруднительно.

Среди всего массива найденной ранненеолитической керамики особняком стоит находка миниатюрной чашки, украшенная отпечатками шнурового штампа. Размеры изделия - диаметр 7 см, высота - 3 см, форма коническая с высоким прямым венчиком. Вся внешняя поверхность чашки украшена очень тонкими наклонными параллельными отпечатками шнурового штампа, под венчиком с внешней стороны нанесен поясок из вертикальных отпечатков этого же штампа. Тем же штампом, поставленным под острым углом, украшен срез венчика. С внутренней стороны венчика вертикальные отпечатки шнурового штампа сгруппированы по 4-5 оттисков отдельными группами, с обширными участками неорнаментированного пространства между ними (рис. 13). Аналоги подобной находке в материалах стоянок Волго-Окского междуречья неизвестны.

Таким образом, как уже было отмечено, остатки посуды с накольчатой орнаментацией и без орнамента среди всего массива верхневолжской керамики стоянки Замостье 2 составляют подавляющее большинство - почти 78\%. Для сравнения: «На стоянке Сахтыш 8 (раскопки 1965-1978 гг.) неорнаментированная и накольчатая посуда составляет $48 \%$ от всего количества верхневолжской керамики, найденной на стоянке, на Торговище 1 (раскопки 1980 г.) - 38\%, на Ивановской 5 (раскопки 1974, 1982 гг.) - 69\%, на Ивановской 3 (раскопки 1972, 1974, 1981 гг.) - 16\%, на Ивановской 7 (раскопки 1973-1975 гг.) - 39\%» [7]. С формально-типологической точки зрения можно считать, что основной комплекс ранненеолитической верхневолжской керамики на стоянке связан с начальным этапом существования этой культуры в Волго-Окском междуречье [7, 8, 10]. Однако проведенное технологическое исследование неорнаментированной керамики показало большую вариабельность и многообразие использованных технологических приемов, что указывает на неоднородность самого массива этой керамики [4]. Выделенные авторами различия, по их мнению, отражают хронологическую разновременность, связанную с неоднократным заселением территории стоянки различными человеческими коллективами [4, с. 172]. С литологической точки зрения, на тех участках памятника, где была прослежена четкая стратиграфия слоев (раскопки 1991, 1995-2000 гг.) [11], слой с ранненеолитической верхневолжской керамикой представляет собой гомогенный горизонт мощностью 10-15 см без видимых нарушений или переотложения. Это, однако, не исключает предположения, что его формирование связано с неоднократными посещениями в течение продолжительного отрезка времени. В связи с этим, в силу объективной невозможности разСамарский научный вестник. 2014. № 3(8) делить ранненеолитический культурный горизонт на отдельные посещения, представляется плодотворным анализ массива полученных для этого слоя радиоуглеродных дат.

Радиоуглеродное датирование образцов из раскопок стоянки Замостье 2

В ходе многолетних исследований стоянки Замостье 2 выявлена достаточно отчетливая стратиграфическая последовательность накопления культурных отложений. Вкратце стратиграфия выглядит следующим образом: 7900 - 7600 л.н. - нижний мезолитический слой, 7400-7100 л.н. - верхний мезолитический слой, 7000 - 6850 л.н. - слой финального мезолита, 6850 - 6200 л.н. - ранненеолитический верхневолжский горизонт, 5800 - 5500 л.н. - слой среднего неолита. Эти данные подкреплены многочисленными естественнонаучными исследованиями и обширной серией радиоуглеродных дат по всем хронологическим периодам [11]. Собственно массив радиоуглеродных датировок для слоя раннего неолита можно разделить по виду датируемого материала (торф, дерево, нагар на керамике) и источнику датирования (культурный слой, отдельные фрагменты керамики, объекты из дерева или части деревянных конструкций, происходящие из культурного слоя). Радиоуглеродное датирование образцов производилось в радиоуглеродной лаборатории ИИМК РАН (Ле), радиоуглеродной лаборатории Геологического института (ГИН), радиоуглеродной лаборатории РГПУ им.Герцена $(\mathrm{Spb})$, Киевской радиоуглеродной лаборатории (Ki), АMC датирование образцов нагара было сделано в лаборатории Ангстром университета г.Упсала (Швеция - Ua).

Данные по датированию нагара на керамике, вмещающим культурные остатки по сапропелю, конструкциям из дерева и обработанной древесине.

Датирование нагара на верхневолжской керамике.

Для датирования остатков нагара на верхневолжской керамике были отобраны образцы, в основном относимые к раннему этапу бытования культуры - фрагменты без орнамента, фрагменты с накольчатой орнаментацией, фрагменты с орнаментом, нанесенным в технике «отступающая лопаточка», еще два отобранных образца являются фрагментами керамики с прочерченным орнаментом и разделительными поясками, выполненными в технике отступающей лопаточки. Всего было получено 19 радиоуглеродных дат (табл. 1). Полученные датировки распределились следующим образом: для керамики без орнамента - 7537 $150 \mathrm{BP}(\mathrm{SPb}-720), 7105 \pm 150 \mathrm{BP}$ $(\mathrm{SPb}-722), 7030 \pm 100 \mathrm{BP}(\mathrm{SPb}-723), 6975 \pm 100 \mathrm{BP}(\mathrm{SPb}-$ $721), \quad 6720 \pm 150 \mathrm{BP} \quad(\mathrm{SPb}-725), 6700 \pm 120 \mathrm{BP} \quad(\mathrm{SPb}-$ $724), \quad 6697 \pm 150 \mathrm{BP} \quad(\mathrm{SPb}-718), \quad 6500 \pm 150 \mathrm{BP} \quad(\mathrm{SPb}-$ 727), 6485 $\pm 150 \mathrm{BP}(\mathrm{SPb}-728), 6433 \pm 150 \mathrm{BP} \quad(\mathrm{SPb}-717)$, $6385 \pm 150 \mathrm{BP}(\mathrm{SPb}-719), 6300 \pm 130$ (Ki-15032) (рис. 14: 1, 5, $7,9-13 ; 15)$; для керамики с накольчатой орнаментацией

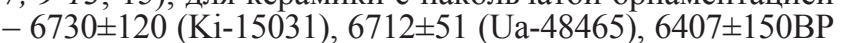
(SPb-726) (рис. 14: 2, 3, 8); для керамики с накольчатым орнаментом и в технике «оступающая лопаточка» $6650 \pm 45$ (Uа-37101) (рис. 14: 4); для керамики с орнаментом в технике «отступающая лопаточка» $-6444 \pm 120$ (Кi-15030) (рис. 14: б); для двух фрагментов керамики с прочерченным орнаментом и поясками в технике отступающей лопаточки получены следующие даты: 6834 63 (Ua-48463), 6541 \pm 45 (Ua-48464). Нетрудно заметить, что большинство полученных датировок практически полностью соответствуют текущим представлениям о времени бытования ранненеолитической верхневолжской культуры на памятнике. В то же время некоторые даты серьезно выпадают из предложенной хронологии и имеют резкое удревнение, как например, $7537 \pm 150 \mathrm{BP}$ (SPb-720) (рис. 15). Причины такого удревнения пока не очень понятны, хотя аналогичное явление мы наблюдаем и на стоянке Сахтыш 2a [12]. С другой стороны, хотя большинство дат и концентрируется в отрезке 6850-6500 л.н., т.е. условно в рамках раннего этапа верхневолжской 
культуры [7; 8, с. 216], остальные даты равномерно распределены практически по всему хронологическому отрезку ее существования. Соответственно возникают вопросы о неоднородности самого комплекса ранней верхневолжской керамики - неорнаментированной керамики и керамики с накольчатым орнаментом, что хорошо видно по результатам датирования нагара на керамике ст. Сахтыш 2a [12]. Дополнительный импульс к этим вопросам дает результат датирования нагара на одном из двух фрагментов верхневолжской керамики с прочерченным орнаментом, который также показал неожиданно древнюю дату для этого типа орнаментации $6834 \pm 63$ (Uа-48463). Это еще раз заставляет задуматься о хронологических рамках разного типа орнаментации посуды верхневолжской культуры.

Датирование вмещающих культурный слой отложений (сапропель)

Радиоуглеродные даты по вмещающим остатки верхневолжской культуры отложениям проводились по образцам сапропеля из раскопа 1989 г. и 1990 г.

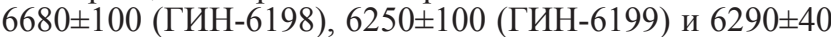
(ГИН-7985) (табл. 1). Никаких очевидных противоречий с современными представлениями о хронологических рамках бытования верхневолжской культуры на памятнике в данном случае нет. Интересно, что для слоя финального мезолита, который прослеживался в раскопах 1990 и 1995-2000 гг., по образцам сапропеля были получены две сходные даты: $6850 \pm 60$ (ГИН-6557) и $6850 \pm 40$ (ГИН-10065); еще две даты были получены по образцам дерева с обработкой из этого же слоя: $6980 \pm 40$ (ГИН-

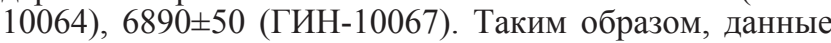
датирования культурных слоев финального мезолита и раннего неолита стоянки Замостье 2 позволяют предположить, что появление носителей верхневолжской культуры с первой керамикой на памятнике, очевидно, происходило позднее указанных датировок в пределах допустимой дельты \pm 50 лет.

Датирование деревянных рыболовных конструкиий

Датирование деревянных рыболовных конструкций верхневолжского слоя (табл. 1). В южной части стоянки работами 1989-2013 гг. было исследовано три сооружения из расщепленных лучин сосны и ели, которые были скреплены между собой полосками из озерного камыша [13, $14,15,16]$. Судя по характеру вмещающих сооружения отложений, в период бытования верхневолжской культуры на памятнике этот участок представлял собой прибрежную водную часть стоянки. Собственно остатки всех трех конструкций залегали в отложениях сапропеля, который содержал немногочисленные находки, в том числе единичные фрагменты верхневолжской керамики (рис.4: 9, 10). Непосредственно под вершами начинался мощный культурный слой мезолитического времени без единой находки фрагментов керамической посуды Полученные даты для двух конструкций (верши 1989 г. и верши с веслом 2011 г.) датируют время их сооружения первой половиной существования верхневолжской культуры 6550 \pm 40 (Beta-283033), 6452 \pm 43 (CNA-1081) - обе даты сделаны по одному образцу лучины с остатками обмотки; 6676 47 (CNA-1342) (дата сделана по

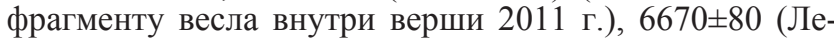
9536), 6539 43 (CNA-1341) - даты сделаны по образцам лучин, перекрывающим весло верши 2011 г.

Датирование образиов древесины со следами обработки

Датирование образца древесины со следами обработки, найденной в верхневолжском слое рядом с деревянными конструкциями, дало практически синхронные с датированием самих конструкций результаты: $6730 \pm 150$ (Ле-9523) и 6646 39 (CNA-1345).

Таким образом, на настоящий момент для верхневолжского слоя стоянки Замостье 2 существуют 33 радиоуглеродные даты, полученные по разным видам материалов: 9 - по образцам обработанной древесины и деревянным конструкциям из слоя, 19 - по образцам нагара на фрагментах верхневолжской керамики, и 5 по образцам сапропеля, вмещавшим культурные остатки. В данной работе в этот массив не включены даты, полученные по вертикальным кольям из раскопа и из русла реки Дубны, поскольку их контекст напрямую не связан с верхневолжским слоем. Анализ всей совокупности дат показывает в первую очередь концентрацию дат в пределах первой половины V тыс. до н.э., что хорошо укладывается в современные представления о временных рамках существования раннего этапа верхневолжской культуры в Волго-Окском междуречье $[7 ; 8 ; 10 ; 17 ; 18$, c. 245]. Необходимо отметить, что данные по радиоуглеродному датированию стоянки Замостье 2 практически полностью совпали с данными по датированию стоянки Сахтыш 2a, где нижняя граница массового распространения ранненеолитической керамики маркируется отметкой $6850 \pm 110$ [10]. По всей видимости, именно эту дату на настоящий момент можно считать началом широкого распространения верхневолжской культуры с ранненеолитической керамикой в Волго-Окском регионе. Завершение этого первого этапа, как показывают данные датирования стоянок Сахтыш 2а и Замостье 2, маркируется отметкой $6500 \pm 100$ [11]. Однако для стоянки Замостье 2 есть небольшая серия дат $(7537 \pm 150 \mathrm{SPb}$ $720,7105 \pm 150 \mathrm{SPb}-722,7030 \pm 100 \mathrm{SPb}-723,6975 \pm 100$ $\mathrm{SPb}-721)$, полученная по образцам нагара верхневолжской керамики с накольчатой орнаментацией и без орнамента, которая демонстрирует явно более древний возраст, чем предполагается. Это же замечание относится к фрагменту с прочерченной орнаментацией, датирование нагара которого показала неожиданно древнюю дату (6834 \pm 63 Ua-48463), хотя и в рамках бытования верхневолжской культуры. С другой стороны, для стоянки Сахтыш 2а авторы определяют момент появления ранненеолитической верхневолжской керамики отметкой $7072 \pm 36-7018 \pm 45$ [19]. Не исключено, что распространение первых керамических традиций в Волго-Окском междуречье происходило не одномоментно - на одних памятниках это произошло раньше (Сахтыш 2a), на других - спустя 100-150 лет (Замостье 2).

Следующий вопрос связан с другой серией дат стоянки Замостье $2(6300 \pm 130 \mathrm{Ki}-15032,6407 \pm 150 \mathrm{SPb}-726$, $6385 \pm 150 \mathrm{SPb}-719)$, которая получена по нагару на фрагментах керамики с накольчатой орнаментацией и без орнамента. Эти даты, наоборот, демонстрируют более молодой возраст и уходят во вторую половину V тыс. до н.э. Причины подобной относительной «молодости» этих датировок также неясны. Возможно, как уже отмечалось исследователями [4], они кроются в неоднородности самого комплекса верхневолжской керамики, относимого к раннему этапу культуры. Очевидно, решение этих вопросов лежит на пути дальнейших комплексных исследований.

\section{СПИСОК ЛИТЕРАТУРЫ}

1. Lozovski V.M. Zamostje 2. Les derniers chasseurs-pêcheurs préhistoriques de la Plaine Russe. Guides archéologiques du «Malgré-Tout». Treignes. Editions de CEDARC, $1996.96 \mathrm{p}$.

2. Лозовский В.М. Переход от лесного мезолита к лесному неолиту в Волго-Окском междуречье (по материалам стоянки Замостье 2) //Неолит- энеолит юга и неолит севера Восточной Европы (новые материалы, исследования, проблемы неолитизации регионов). СПб., 2003. С.219-240.

3. Лозовский В.М., Лозовская О.В., Клементе Конте И. Замостье 2. Озерное поселение древних рыболовов эпохи мезолита-неолита в бассейне Верхней Волги. СПб.: ИИМК PAH, 2013. $240 \mathrm{c}$

4. Мазуркевич А.Н., Долбунова Е.В., Кулькова М.А. Ранненеолитические керамические комплексы памятника Замостье 2: технология, типология, хронология // Замостье 2. Озерное поселение древних рыболовов эпохи мезолита-неолита в бассейне Верхней Волги. СПб.: Самарский научный вестник. 2014. № 3(8) 
ИИМК РАН, 2013. С.158-181.

5. Крайнов Д.А.. Верхневолжская культура // Неолит северной Евразии. Археология. М.: Наука, 1996. С. 166-172.

6. Костылева Е.Л. Хронология, периодизация и локальные варианты верхневолжской культуры: Автореферат дисс. ... канд. ист. наук. М., 1987.

7. Костылева Е.Л.. Ранненеолитическая керамика верхнего Поволжья // Тверской археологический сборник. 1994. Вып.1. С. 53-57.

8. Костылева Е.Л. Основные вопросы неолитизации центра Русской равнины (особенности неолитизации лесной зоны) // Неолит- энеолит Юга и неолит Севера Восточной Европы. СПб., 2003. С. 213-218.

9. Крайнов Д.А., Хотинский Н.А. Верхневолжская ранненеолитическая культура // Советская археология 1977. № 3. С.42-68.

10. Зарецкая Н.Е., Костылёва Е.Л. Радиоуглеродная хронология начального этапа верхневолжской ранненеолитической культуры: По материалам стоянки Сахтыш 2A // Российская археология. 2008. № 1. С. 5-14.

11. Lozovski V., Lozovskaya O., Mazurkevich A., Hookk D., Kolosova M. Late Mesolithic-Early Neolithic human adaptation to environmental changes at an ancient lake shore: The multi-layer Zamostje 2 site, Dubna River floodplain, Central Russia //Quaternary International, Volume 324, Human dimensions of palaeoenvironmental change: Geomorphic processes and geoarchaeology. 190 P. (4 March 2014) Ed. by M. Bronnikova and A. Panin. 2014. P.146-161

12. Hartz S., Kostyleva E., Piezonka H., Terberger T., Tsydenova N., Zhilin M.G. 2012. Hunter-gatherer pottery and charred residue dating: New results on early ceramics in the north Eurasian forest zone // Radiocarbon. Vol. 54, N 3-4. P. 1033-1048.

13. Лозовский В.М. Рыболовные сооружения на стоянке Замостье-2 в контексте археологических и этнографических данных // Древности Залесского края. Материалы к международной конференции «Каменный век европейских равнин: объекты из органических материалов и структура поселений как от- ражение человеческой культуры», Сергиев Посад, 1-5 июля 1997. С.52-65.

14. Lozovski V. Archaeological and ethnographic data for fishing structures // Bog Bodies, Sacred Sites and Wetland Archaeology. 1999. P.139-145.

15. Лозовская О.В., Лозовский В.М., Мазуркевич А.Н., Клементе Конте И., Гассьот Э. Деревянные конструкции на стоянке каменного века Замостье 2: новые данные // Краткие сообщения института археологии PAH, №227, 2012. С.250-259.

16. Лозовский В.М., Лозовская О.В., Клементе-Конте И., Мазуркевич А.Н., Гассьот-Бальбе Э. Деревянные рыболовные конструкции на стоянке каменного века Замостье 2 // Замостье 2. Озерное поселение древних рыболовов эпохи мезолита-неолита в бассейне Верхней Волги. СПб.: ИИМК PAH, 2013. C.46-75.

17. Костылева Е.Л., Зарецкая Н.Е. Новые данные по начальному этапу неолита Волго-Окского междуречья // Проблемы хронологии и этнокультурных взаимодействий в неолите Евразии (хронология неолита, особенности культур и неолитизация регионов, взаимодействия неолитических культур в Восточной и Средней Европе). ИИМК РАН. СПб., 2004.С. 52-53.

18. Жилин М.Г., Костылёва Е.Л., Зарецкая Н.Е., Спиридонова Е.А. Природное окружение и история заселения многослойного памятника Сахтыш 2a // Природная среда и модели адаптации озерных поселений в мезолите и неолите лесной зоны Восточной Европы: Материалы Международной научной конференции. Санкт-Петербург, 19-21 мая 2014 г. СПб.: ИИМК РАН, 2014. C. 41-45.

19. Энговатова А.В. Хронология эпохи неолита ВолгоОкского междуречья // Тверской Археологический сборник. 1998. Вып. 3. С. 132-134.

Авторы высказывают признательность А. Н. Климову и В. В. Вишневскому за помощь, оказанную в подготовке данной работы.

Работа выполнена при финансовой поддержке гранта РФФИ №11-06-00090-а, 13-06-12057 офи-м.

\section{ИЛЛЮСТРАЦИИ}

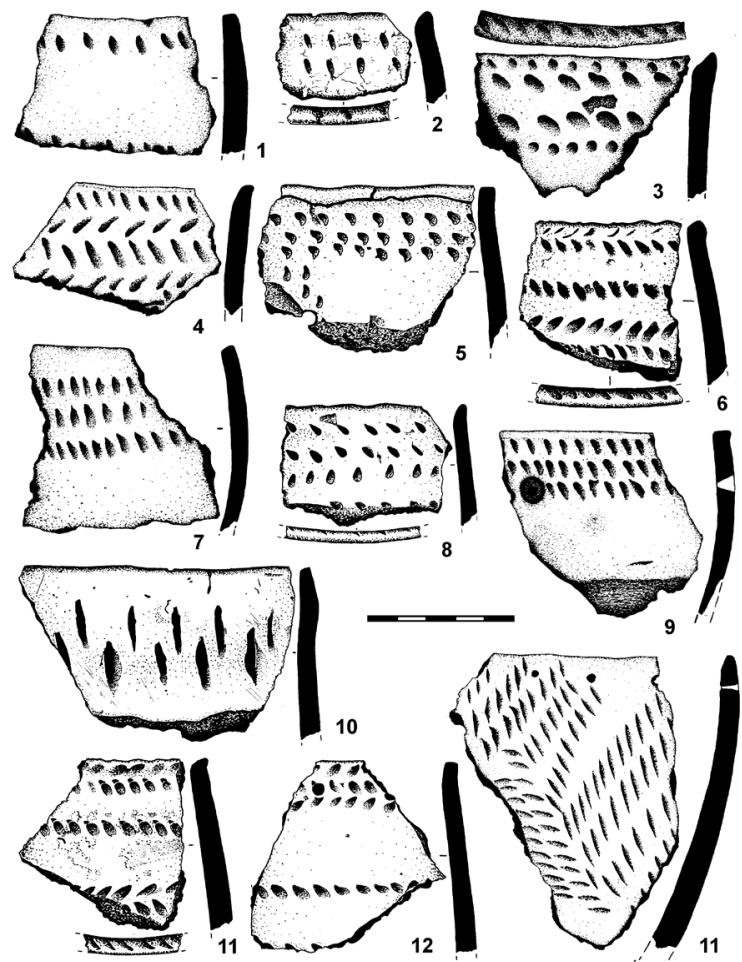

Рис. 1. Стоянка Замостье 2. ранненеолитическая верхневолжская керамика с тычково-накольчатой орнаментацией 


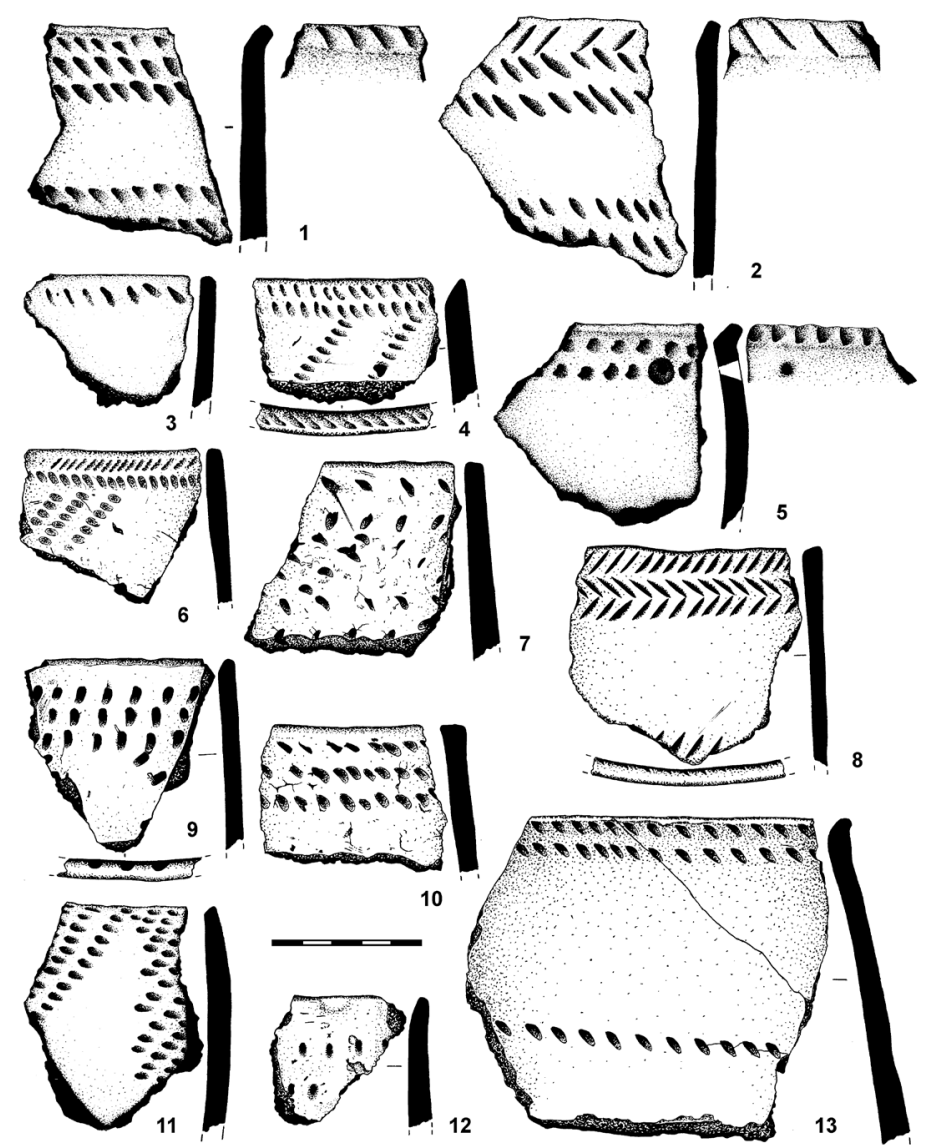

Рис. 2. Стоянка Замостье 2. ранненеолитическая верхневолжская керамика с тычково-накольчатой орнаментацией

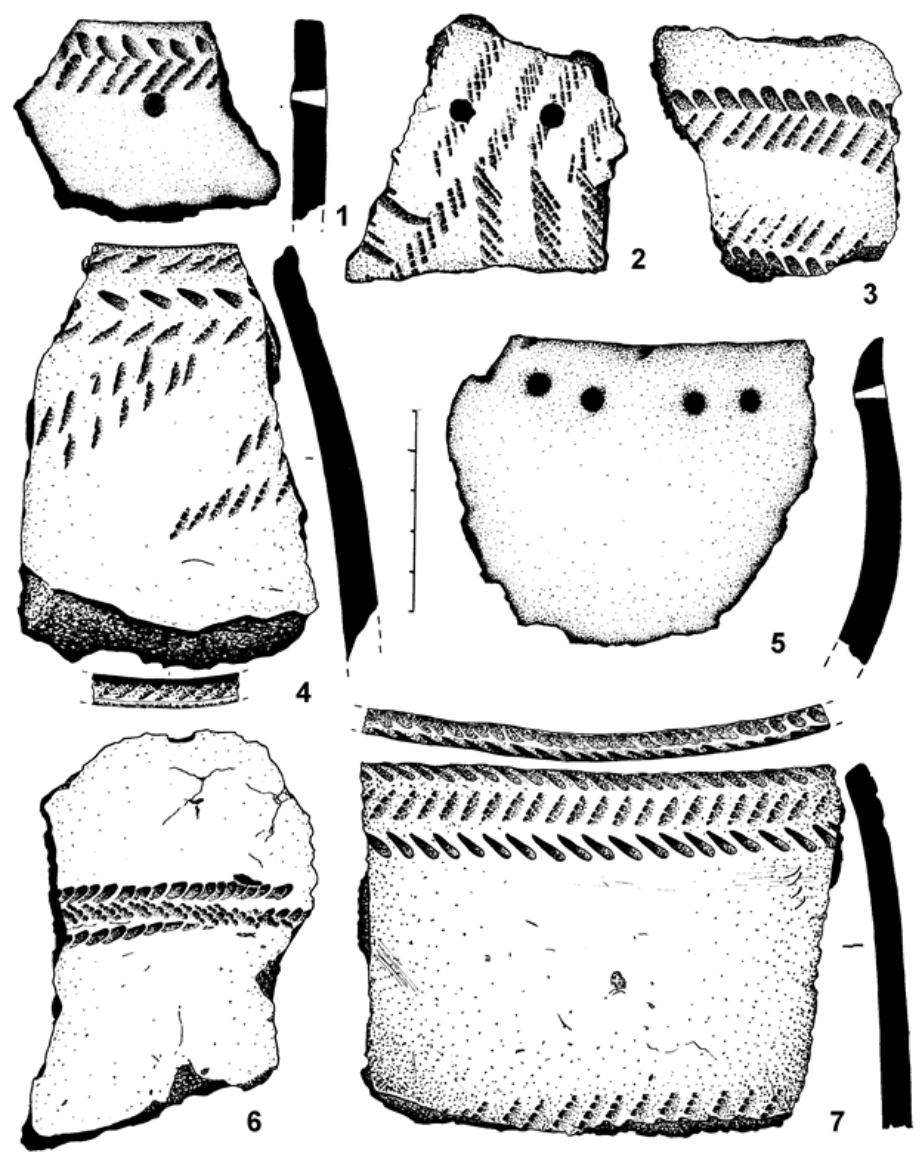

Рис. 3. Стоянка Замостье 2. ранненеолитическая верхневолжская керамика с орнаментом из короткозубчатого штампа $(1-4,5,7)$ и без орнамента (5) 


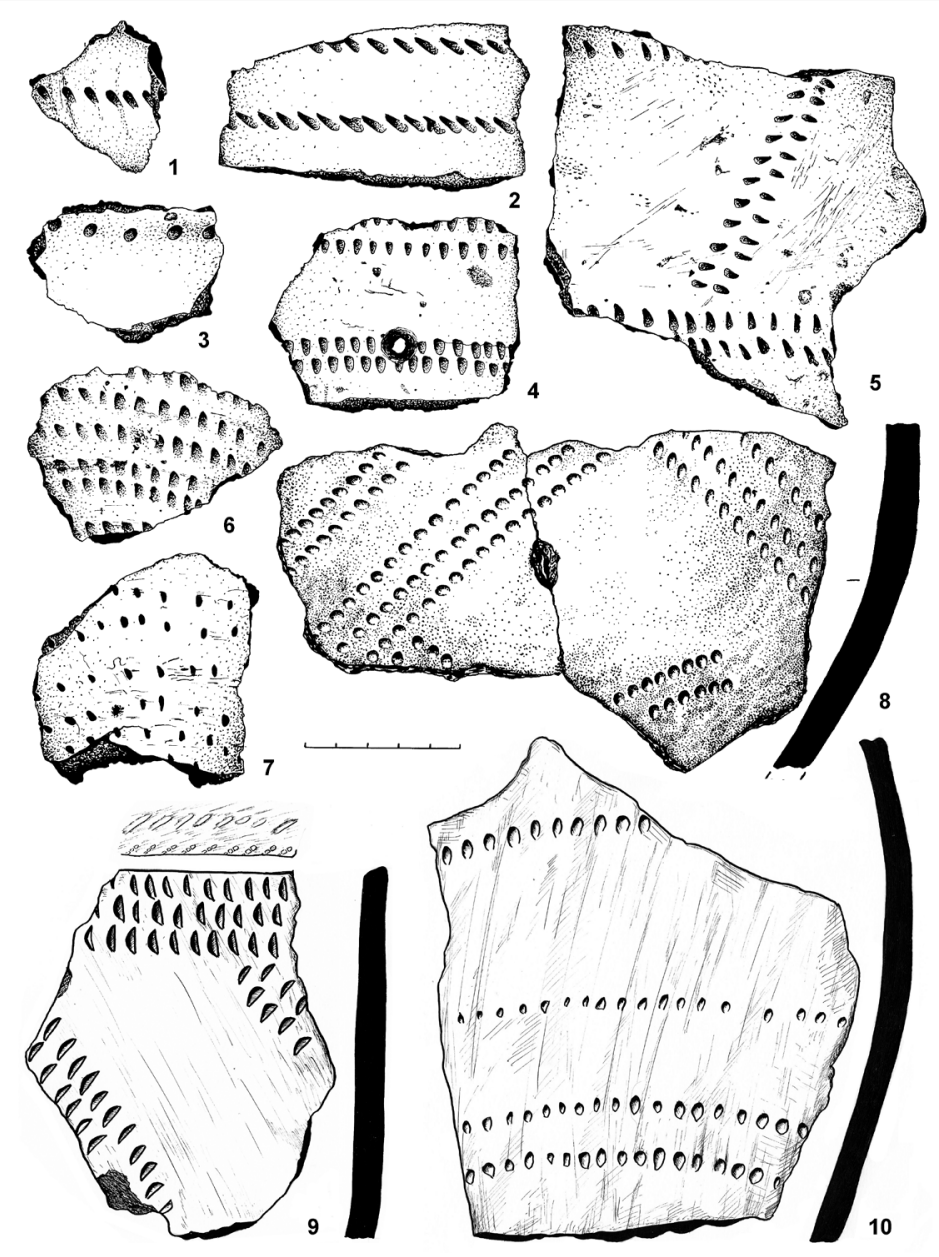

Рис. 4. Стоянка Замостье 2. ранненеолитическая верхневолжская керамика с тычково-накольчатой орнаментацииеи

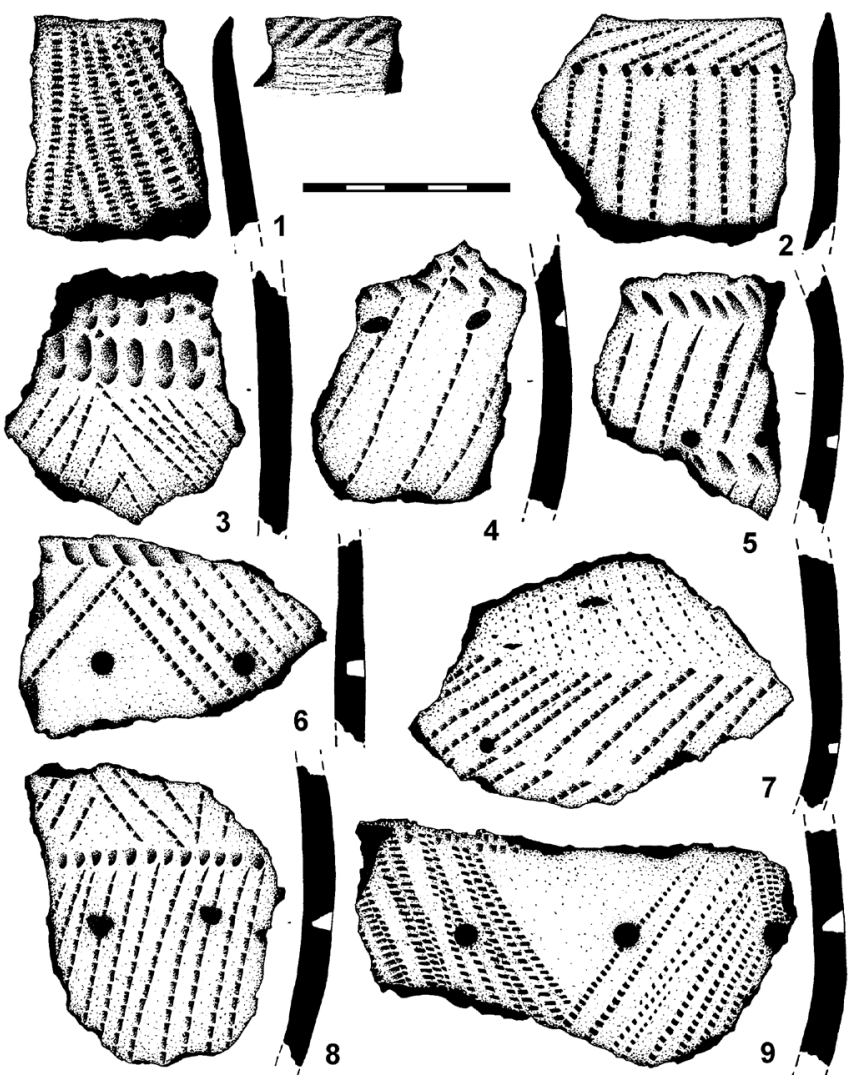

Рис. 5. Стоянка Замостье 2. ранненеолитическая верхневолжская керамика с орнаментом «длинная гребенка» 

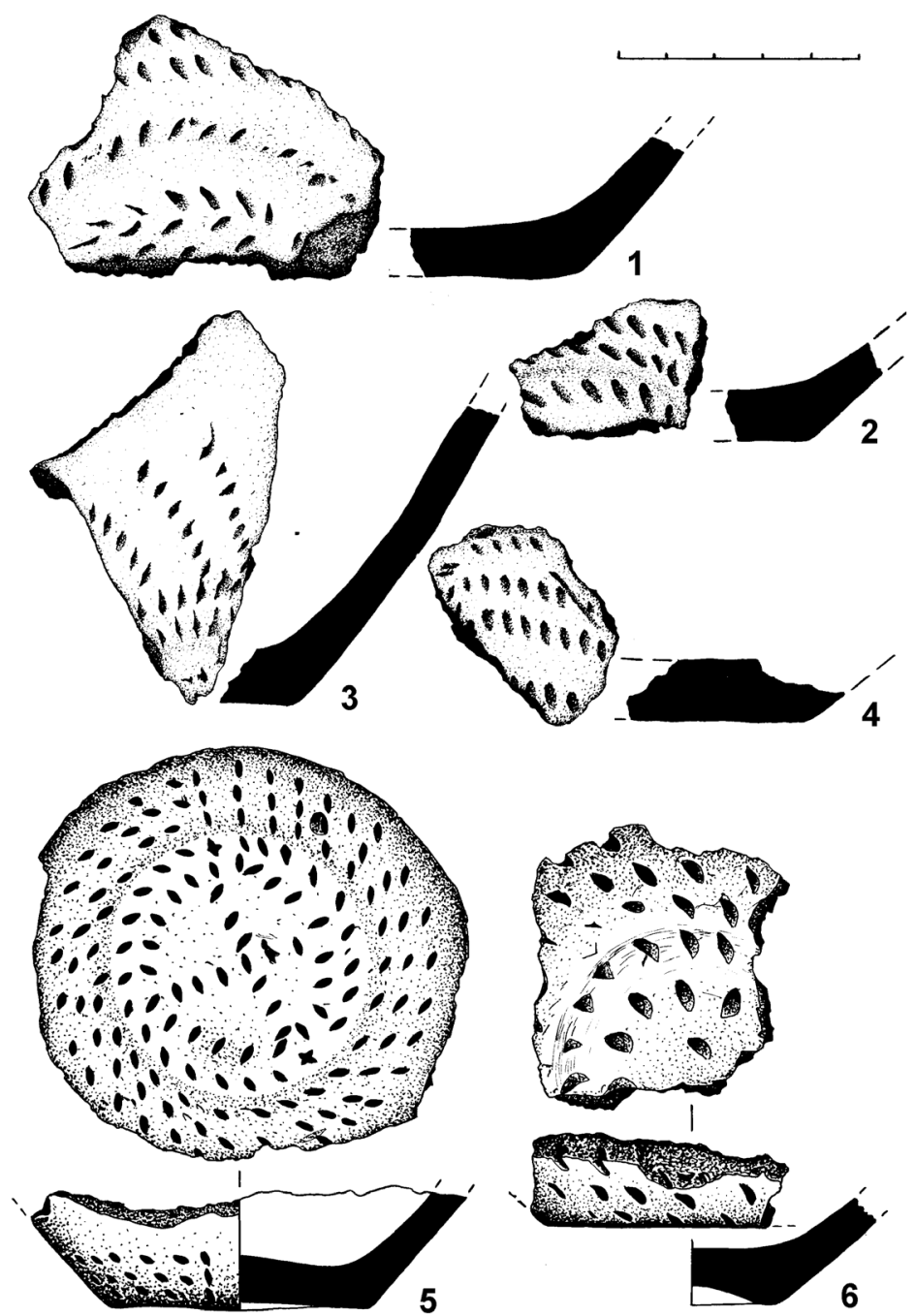

Рис. 6. Стоянка Замостье 2. ранненеолитическая верхневолжская керамика с тычково-накольчатой орнаментаичией, донйа
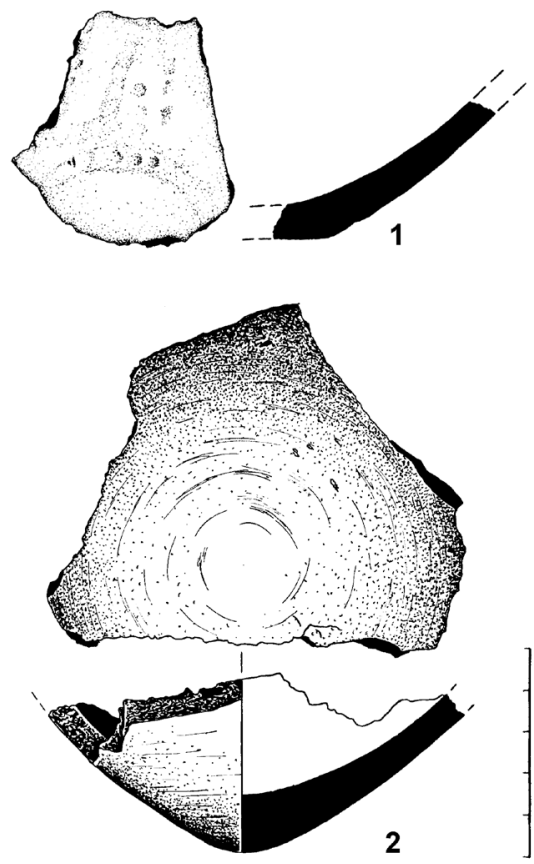

Рис. 7. Стоянка Замостье 2. ранненеолитическая верхневолжская керамика с тычково-накольчатой орнаментацией и без орнамента, дониа 


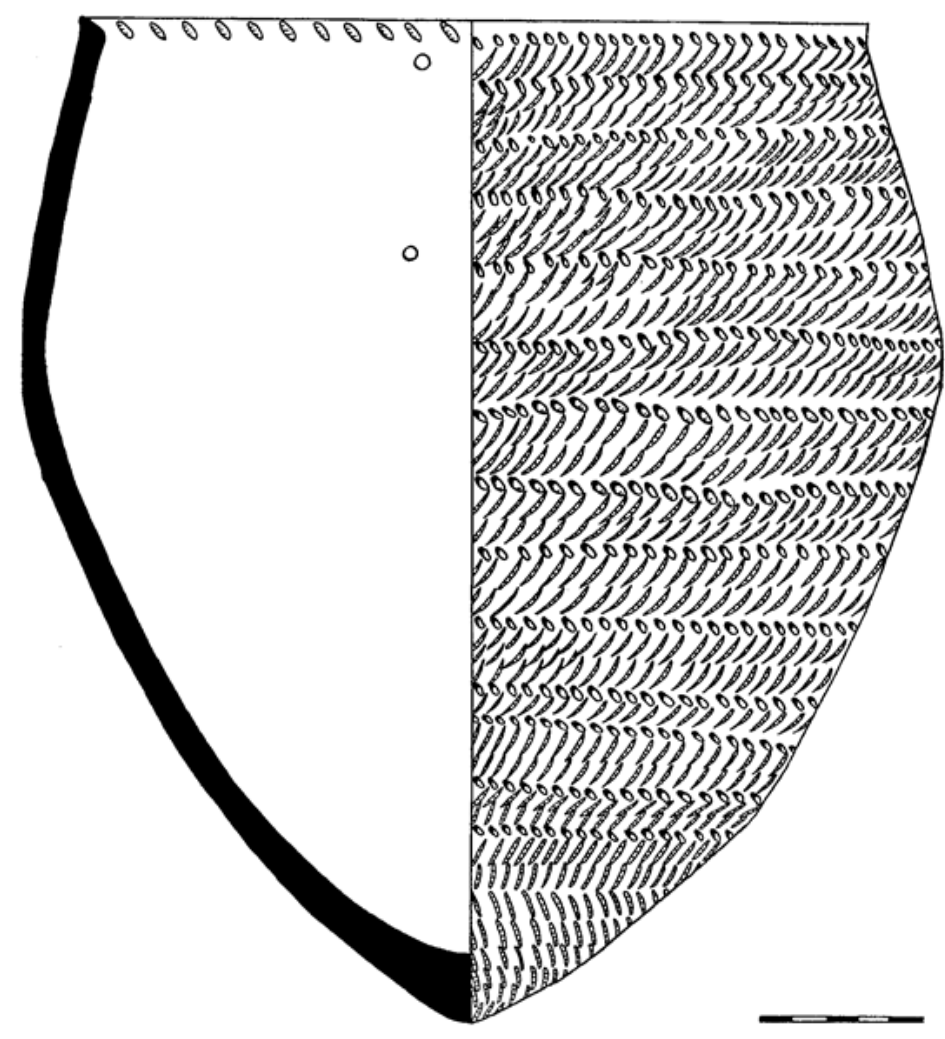

Рис. 8. Стоянка Замостье 2. Сосуд с короткозубчатым орнаментом, нанесенным в отступающей технике (ранненеолитический комплекс)

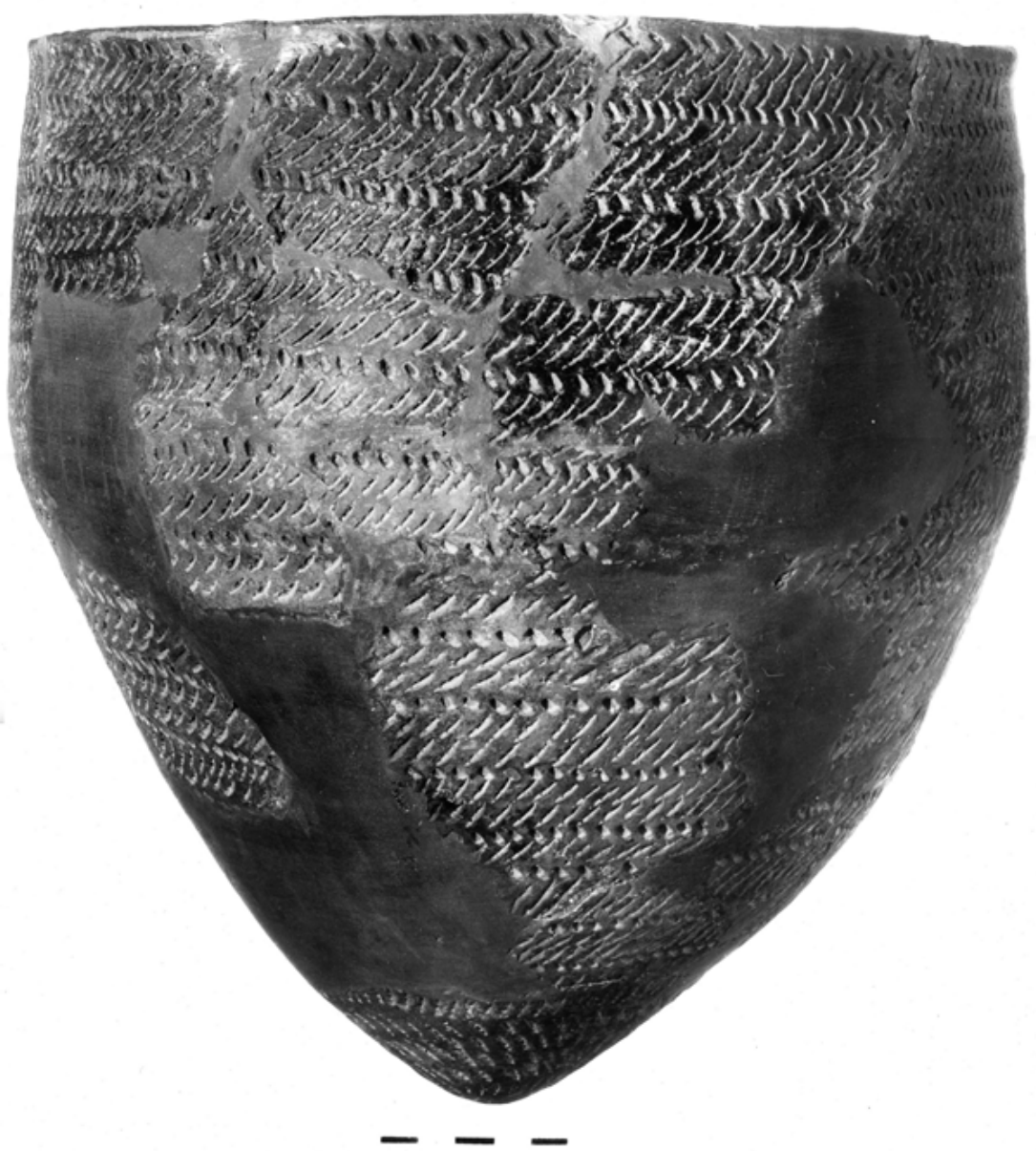

Рис. 9. Стоянка Замостье 2. Сосуд с короткозубчатым орнаментом, нанесенным в отступающей технике (ранненеолитический комплекс) 


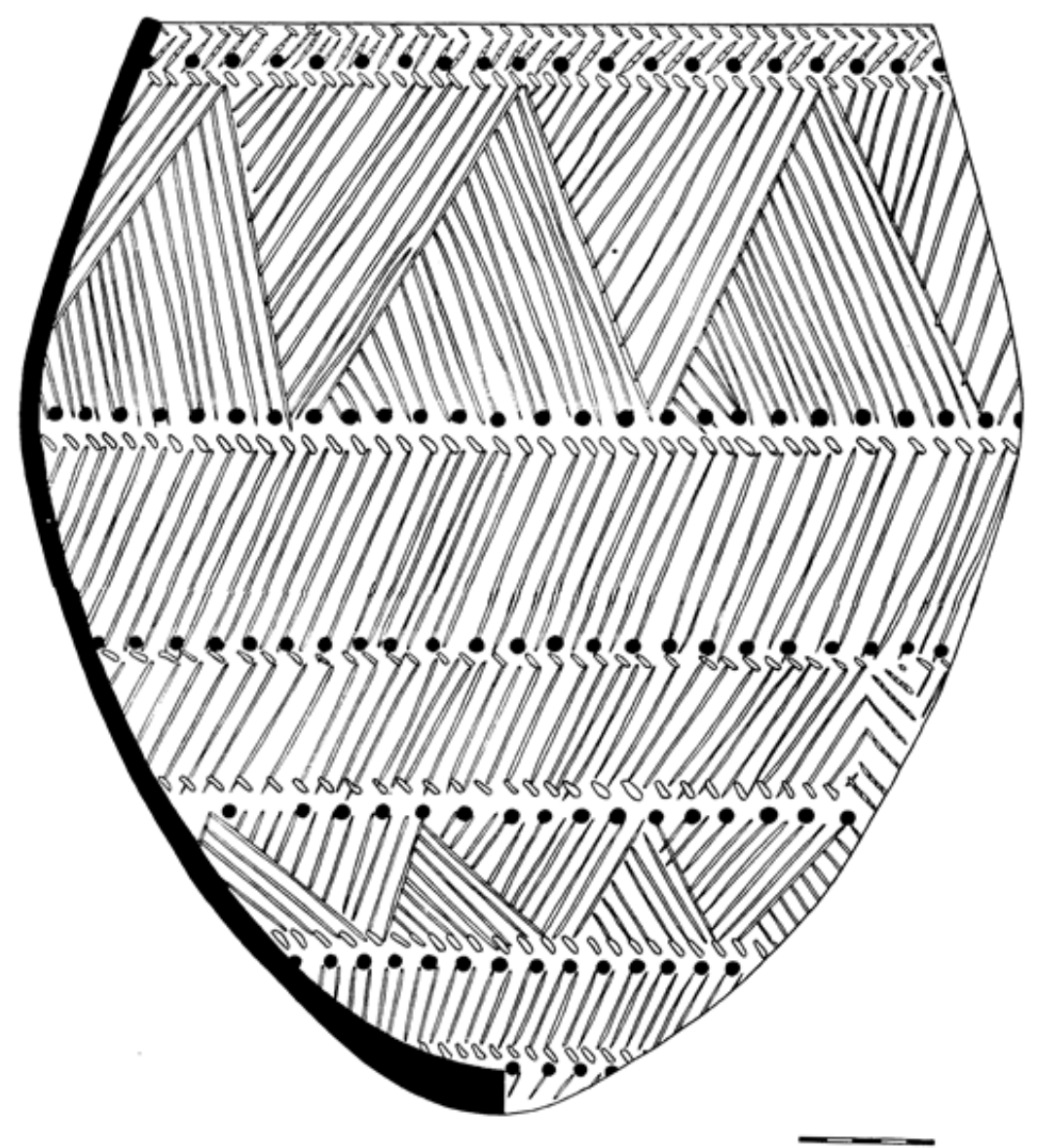

Рис. 10. Стоянка Замостье 2. Сосуд с прочерченным орнаментом (ранненеолитический комплекс)
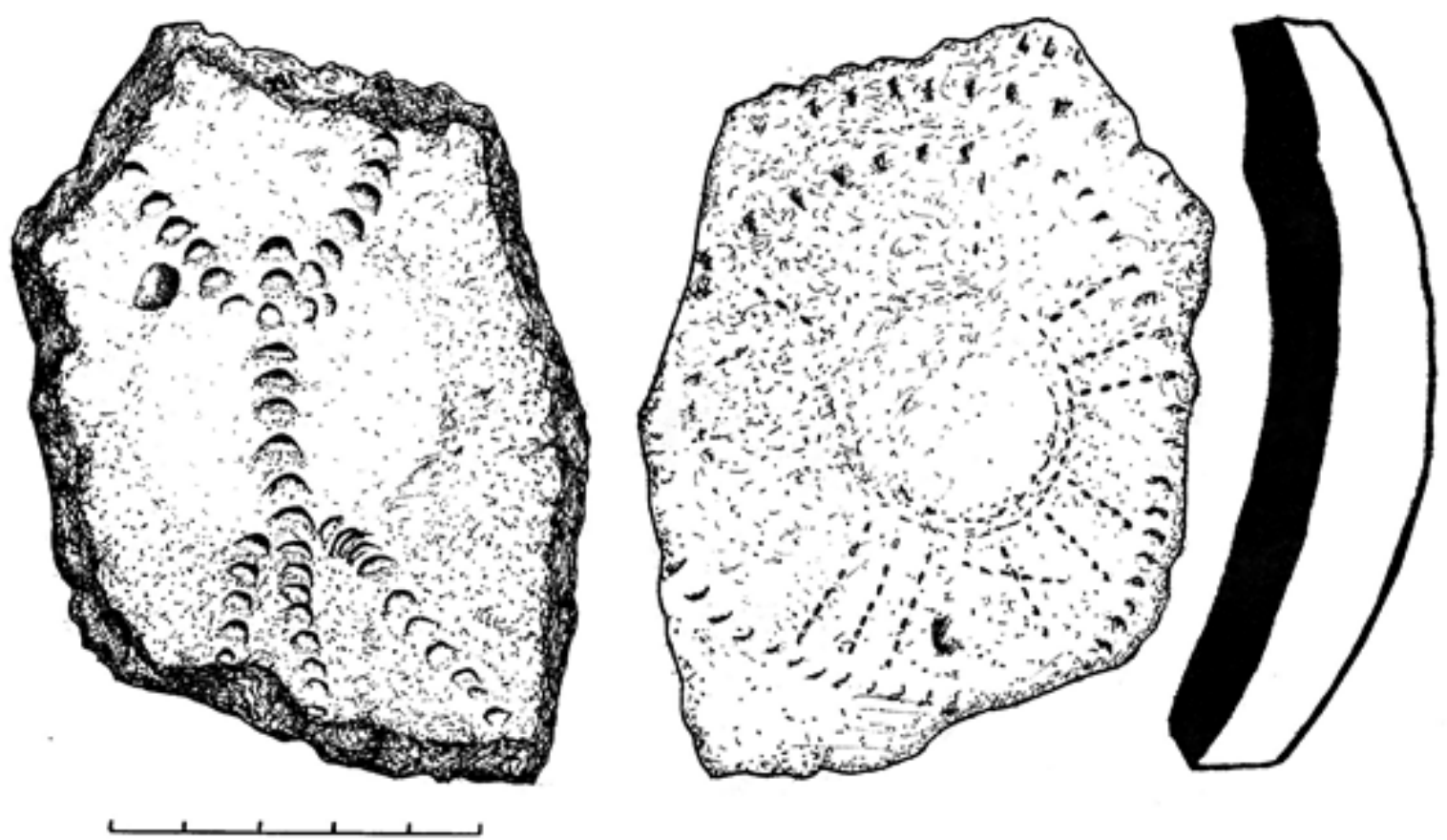

Рис. 11. Стоянка Замостье 2. ранненеолитическая верхневолжская керамика: фрагмент дониа с изображением человека на внутренней стороне 


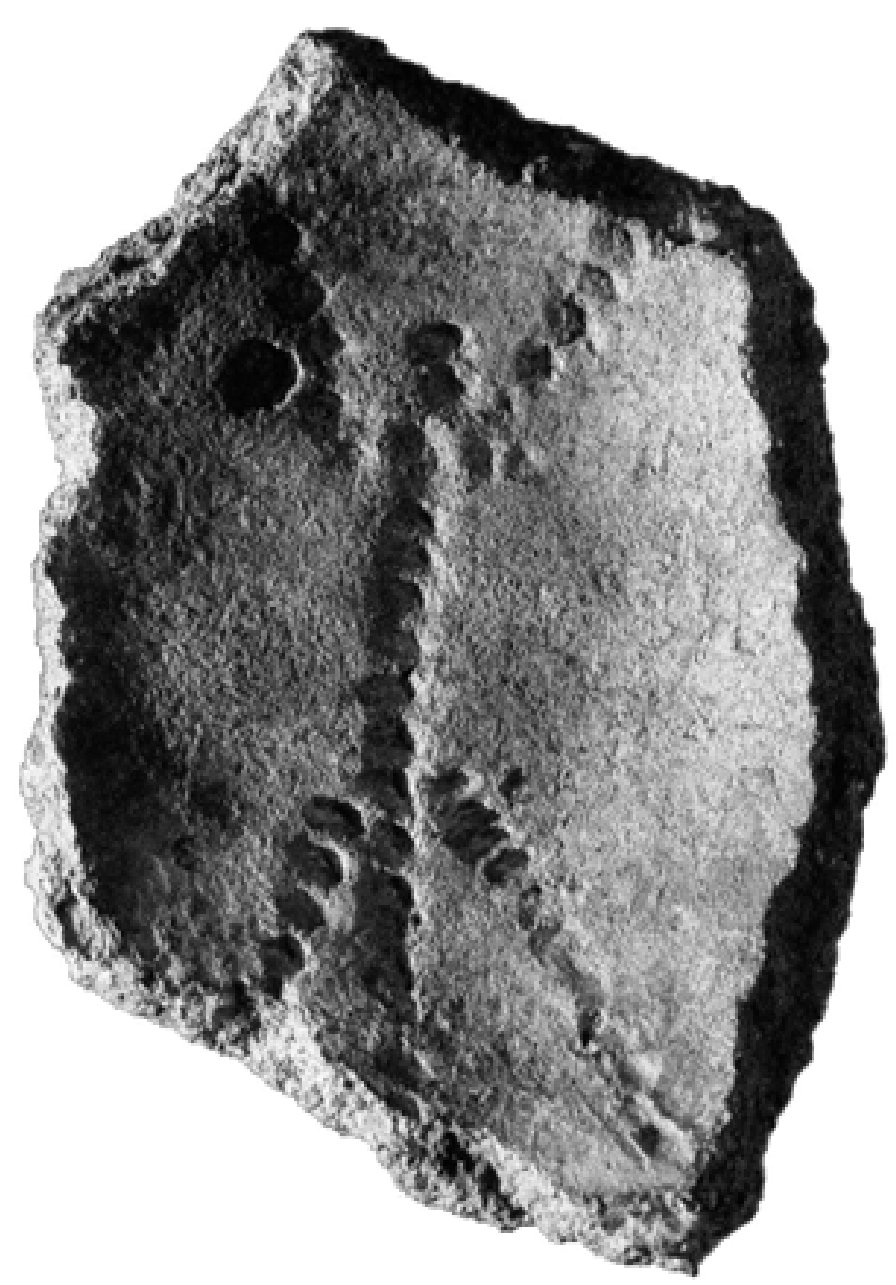

Рис. 12. Стоянка Замостье 2. ранненеолитическая верхневолжская керамика: фрагмент дониа с изображением человека на внутренней стороне
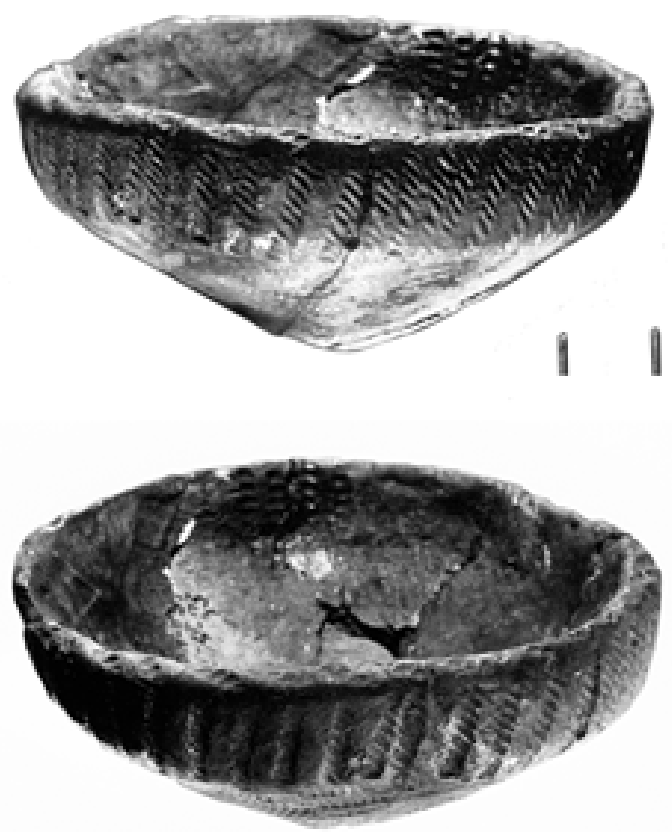

\section{I I I}

Рис. 13. Стоянка Замостье 2. Чашка с отпечатками шнурового штампа (ранненеолитический комплекс) 


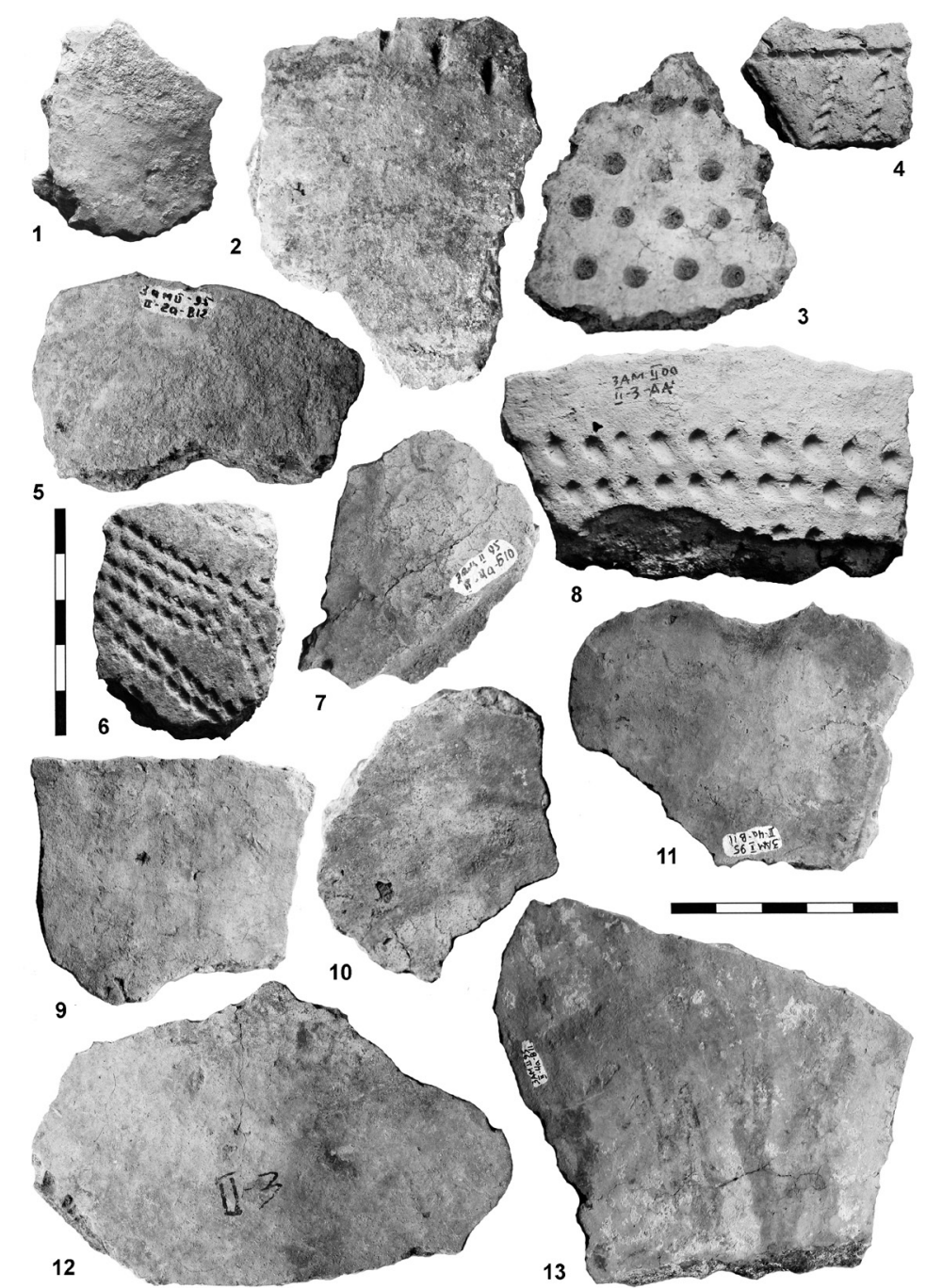

Рис. 14. Стоянка Замостье 2. ранненеолитическая верхневолжская керамика: фрагменты керамики, нагар которых

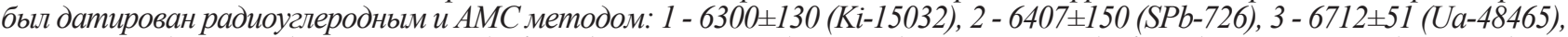

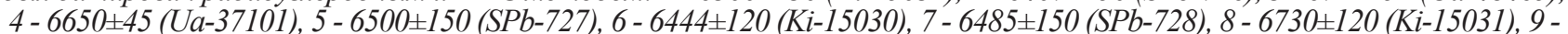

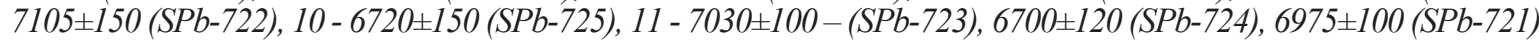

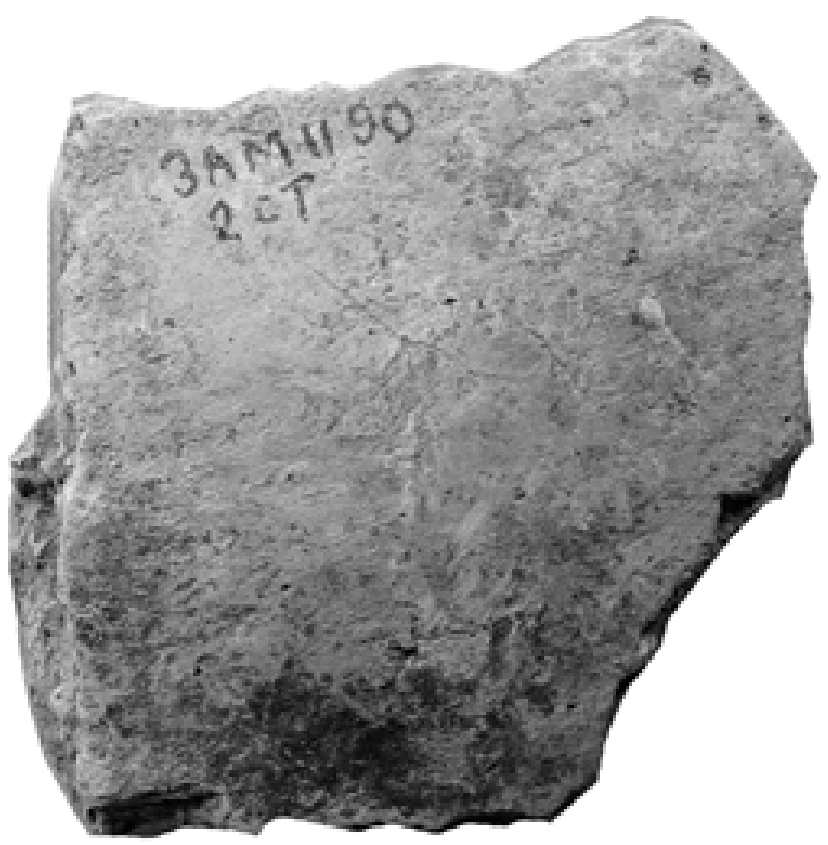

Рис. 15. Стоянка Замостье 2. ранненеолитическая верхневолжская керамика: фрагмент керамики без орнамента, нагар которого был датирован радиоуглеродным методом - $7537 \pm 150$ (SPb-720) 
В.М. Лозовский, О.В. Лозовская, Г.И. Зайцева, Г. Поснерт, М.А. Кулькова КОМПЛЕКС ВЕРХНЕВОЛЖСКОЙ КЕРАМИКИ РАННЕНЕОЛИТИЧЕСКОГО СЛОЯ ...

Таблица 1 - Радиоуглеродные и АМС даты слоя финального мезолита и раннего неолита (верхневолжская культура) стоянки Замостье 2

\begin{tabular}{|c|c|c|c|c|c|c|c|}
\hline $\begin{array}{l}\text { № } \\
\text { лаборатории }\end{array}$ & $\mathrm{C} 14$ & $2 \sigma$ & & $\begin{array}{l}\text { Год } \\
\text { раскопо } \\
\text { к }\end{array}$ & & слой & $\begin{array}{l}813 C \% \\
\text { VPDB }\end{array}$ \\
\hline \multicolumn{8}{|c|}{ деревянные конструкции } \\
\hline Beta-283033 & $6550 \pm 40$ & $\begin{array}{l}5560- \\
5470 \mathrm{BC}\end{array}$ & верша 1989 г. с обмоткой, кв.1, слой 5, №86, -423 & 2010 & дереро (сосна) & BBK & \\
\hline CNA-1081 & $6452 \pm 43$ & $\begin{array}{l}5482- \\
5330 \mathrm{BC}\end{array}$ & верша 1989 г. с обмоткой, кв.1, слой 5, №86, -423 & 2010 & дереро (сосна) & BBK & \\
\hline CNA-1342 & $6676 \pm 47$ & $\begin{array}{l}5671- \\
5510 \mathrm{BC}\end{array}$ & весло верши 2011 /II-4а-Б9'/2, -383, & 2011 & дереро (вяз) & Bвк & \\
\hline Лe-9536 & $6670 \pm 80$ & $\begin{array}{l}5714- \\
5482 \mathrm{BC}\end{array}$ & $\begin{array}{l}\text { верша } 2011 \text { г., лучины над веслом №11,12,17,18,19, кв.699', - } \\
\text { 383-389 (верх) }\end{array}$ & 2011 & дереро (сосна) & BBK & \\
\hline CNA-1341 & $6539 \pm 43$ & $\begin{array}{l}5567- \\
5465 \mathrm{BC}\end{array}$ & $\begin{array}{l}\text { верша } 2011 \text { г., лучина над веслом №11, II-4а-Б9', -383-386, } \\
\text { сосна }\end{array}$ & 2011 & дереро (сосна) & BBK & \\
\hline \multicolumn{8}{|c|}{ дерево с обработкой из слоя } \\
\hline Лe-9523 & $6730 \pm 150$ & $\begin{array}{l}5921- \\
5464 \mathrm{BC}\end{array}$ & ствол березы с обработкой конца, II-5а-АБ8' -383-399 & 2011 & дереро (береза) & BBK & \\
\hline CNA-1345 & $6646 \pm 39$ & $\begin{array}{l}5635- \\
5510 \mathrm{BC}\end{array}$ & ствол березы с обработкой конца, II-5а-АБ8' -383-399 & 2011 & дереро (береза) & ВвК & \\
\hline ГИН-10064 & $6980 \pm 40$ & $\begin{array}{l}5980- \\
5750 \mathrm{BC}\end{array}$ & образцы дерева из слоя 6 & 1996/ 6 & дереро & $\begin{array}{l}\text { финальный } \\
\text { мезолит }\end{array}$ & \\
\hline Гин-10067 & $6890 \pm 50$ & $\begin{array}{l}5890- \\
5670 \mathrm{BC}\end{array}$ & образцы дерева из слоя 5 & $1996 / 5$ & дереро & $\begin{array}{l}\text { финальный } \\
\text { мезолит }\end{array}$ & \\
\hline \multicolumn{8}{|c|}{ нагар на фрагментах керамики } \\
\hline Ki-15030 & $6444 \pm 120$ & $\begin{array}{l}5650- \\
5050 \mathrm{BC}\end{array}$ & $\begin{array}{l}\text { фр-т керамики с орнаментом в технике "отступающая } \\
\text { лопаточка }\end{array}$ & 1995 & нагар & BBK & \\
\hline Ki-15031 & $6730 \pm 120$ & $\begin{array}{l}5890- \\
5470 \mathrm{BC}\end{array}$ & фр-т керамики с накольчатым орнаментом & $2000 / 3$ & нагар & BBK & \\
\hline Ki-15032 & $6300 \pm 130$ & $\begin{array}{l}5550- \\
4900 \mathrm{BC}\end{array}$ & фр-т керамики без орнамента & 1995 & нагар & BBK & \\
\hline Ua-37101 & $6650 \pm 45$ & $\begin{array}{l}5640- \\
5480 \mathrm{BC}\end{array}$ & $\begin{array}{l}\text { фр-т керамики с накольчатым орнаментом и орнаментом в } \\
\text { технике "отступающая лопаточка }\end{array}$ & $1995 / 3$ & нагар & ВBК & \\
\hline SPb-720 & $7537 \pm 150$ & $\begin{array}{l}6700- \\
6050 \mathrm{BC}\end{array}$ & фр-т керамики без орнамента & 1990:II & нагар & BBK & \\
\hline SPb-721 & $6975 \pm 100$ & $\begin{array}{l}6030- \\
5670 \mathrm{BC}\end{array}$ & $\phi \mathrm{p}-\mathrm{T}$ керамики без орнамента & 1995 & $\begin{array}{l}\text { нагар с } \\
\text { косточками } \\
\text { калины }\end{array}$ & BBK & \\
\hline SPb-717 & $6433 \pm 150$ & $\begin{array}{l}5650- \\
5000 \mathrm{BC}\end{array}$ & $\phi p$-т керамики 6 ез орнамента & 1995 & нагар & BBK & \\
\hline SPb-722 & $7105 \pm 150$ & $\begin{array}{l}6350- \\
5650 \mathrm{BC}\end{array}$ & $\phi p-т$ керамики без орнамента & 1995 & нагар & BBK & \\
\hline SPb-718 & $6697 \pm 150$ & $\begin{array}{l}5900- \\
5300 \mathrm{BC}\end{array}$ & $\phi$ р-т керамики без орнамента & 1995 & нагар & BBK & \\
\hline $\mathrm{SPb}-723$ & $7030 \pm 100$ & $\begin{array}{l}6080- \\
5710 \mathrm{BC}\end{array}$ & $\phi p-т$ керамики $6 е з$ орнамента & 1995 & нагар & BBK & \\
\hline SPb-724 & $6700 \pm 120$ & $\begin{array}{l}5848- \\
5466 \mathrm{BC}\end{array}$ & фр-т керамики без орнамента & 1991 & нагар & BBK & \\
\hline SPb-725 & $6720 \pm 150$ & $\begin{array}{l}6000- \\
5350 \mathrm{BC}\end{array}$ & $\phi p-т$ керамики без орнамента & 1995 & нагар & BBK & \\
\hline SPb-726 & $6407 \pm 150$ & $\begin{array}{l}5650- \\
5000 \mathrm{BC}\end{array}$ & фр-т керамики с накольчатым орнаментом & 1995 & нагар & BBK & \\
\hline SPb-727 & $6500 \pm 150$ & $\begin{array}{l}5723- \\
5207 \mathrm{BC}\end{array}$ & $\phi p-т$ керамики без орнамента & 1995 & нагар & BвK & \\
\hline $\mathrm{SPb}-728$ & $6485 \pm 150$ & $\begin{array}{l}5750- \\
5050 \mathrm{BC}\end{array}$ & $\phi \mathrm{p}-\mathrm{T}$ керамики $6 е з$ орнамента & 1995 & нагар & BBK & \\
\hline SPb-719 & $6385 \pm 150$ & $\begin{array}{l}5621- \\
5008 \mathrm{BC}\end{array}$ & $\phi p-т$ керамики без орнамента & 1995 & нагар & BBK & \\
\hline Ua-48463 & $6834 \pm 63$ & $\begin{array}{l}5870- \\
5626 \mathrm{BC}\end{array}$ & $\begin{array}{l}\text { фр-т керамики с прочерченным орнаментом и орнаментом } \\
\text { в технике "отступающая лопаточка" }\end{array}$ & 1990 & нагар & BBK & $-22,8$ \\
\hline Ua-48464 & $6541 \pm 45$ & $\begin{array}{l}5615- \\
5382 \mathrm{BC}\end{array}$ & $\begin{array}{l}\text { фр-т керамики с прочерченным орнаментом и орнаментом } \\
\text { в технике "отступающая лопаточка" } \\
\end{array}$ & 1990 & нагар & BBK & $-27,3$ \\
\hline Ua-48465 & $6712 \pm 51$ & $\begin{array}{l}5717- \\
5544 \mathrm{BC}\end{array}$ & $\begin{array}{l}\text { фр-т керамики с накольчатым орнаментом и округлыми } \\
\text { оттисками }\end{array}$ & 1990 & нагар & BвK & $-26,1$ \\
\hline \multicolumn{8}{|c|}{ датирование образцов слоя - сапропель } \\
\hline ГИН-6198 & $6680 \pm 100$ & $5780-$ & Зам 2 89, раскоп I, кв.4, обр.3 & 1989 & сапропель & BBK & \\
\hline & & $5460 \mathrm{BC}$ & & & & & \\
\hline Гин-6199 & $6250 \pm 100$ & $\begin{array}{l}5500- \\
4950 \mathrm{BC}\end{array}$ & Зам 2 89, раскоп I, кв.4, обр.4 & 1989 & сапропель & BBK & \\
\hline гин-6557 & $6850 \pm 60$ & $\begin{array}{l}5880- \\
5630 \mathrm{BC}\end{array}$ & $\begin{array}{l}\text { Зам } 2 \text { 90, раскоп II, кв.В2, верх слоя } 6 \text { (с ракушкой), глуб.- } \\
2,59 \text { м }\end{array}$ & $1990 / 6$ & сапропель & $\begin{array}{l}\begin{array}{l}\text { финальный } \\
\text { мезолит }\end{array} \\
\end{array}$ & \\
\hline гин-7985 & $6290 \pm 40$ & $\begin{array}{l}5370- \\
5200 \mathrm{BC}\end{array}$ & Зам 2 90, раскоп II, кв.А1, слой 5 & $1990 / 5$ & сапропель & BBK & \\
\hline гин-10065 & $6850 \pm 40$ & $\begin{array}{l}5840- \\
5650 \mathrm{BC}\end{array}$ & Зам 2 96, обр.3, слой 5, в/мез & $1996 / 5$ & сапропель & $\begin{array}{l}\begin{array}{l}\text { финальный } \\
\text { мезолит }\end{array} \\
\end{array}$ & \\
\hline
\end{tabular}




\section{EARLY NEOLITHIC POTTERY COMPLEX OF THE UPPER VOLGA CULTURE FROM SITE ZAMOSTJE 2: TYPOLOGICAL COMPOSITION AND CHRONOLOGICAL FRAMES} (C)2014

V. M.Lozovski, candidate of history sciences, senior researcher, Paleolithic Department, Institute for the History of material culture St.-Petersbourg, St.-Petersbourg (Russia)

Sergiev-Posad History and Art museum Sergiev Posad, (Russia)

O. V.Lozovskaya, candidate of history sciences, researcher, Experimental and Use-wear analysis laboratory

Institute for the History of material culture St.-Petersbourg, St.-Petersbourg (Russia), Sergiev-Posad History and Art museum Sergiev Posad (Russia)

G. I. Zaitceva, , candidate of chemistry sciences, senior researcher, Laboratory of archaeological technologies

Institute for the History of material culture RAS St.Petersburg, (Russia)

Göran Possnert, Professor, doctor, The Angström Laboratory

University of Uppsala, Uppsala (Sweden)

M. A. Kulkova, candidate of geological and mineralogical sciences, associate professor of the Department of Geology and geoecology

Herzen State Pedagogical University, St.Petersburg (Russia)

Russian State Pedagogical University, St.Petersburg (Russia)

Annotation: The paper describes the complex of Early Neolithic Upper Volga culture pottery from site Zamostje 2. The analysis revealed that the vast majority of ceramics found during the excavation of site belong to the first stage of development of the Upper Volga culture - ceramics without ornaments and fragments with ornaments comprised of small dots and notches. Conducted extensive radiocarbon dating by different kinds of materials made it possible to determine the time of existence of the Upper Volga culture on the site Zamostje 2 within the 6850 - 6200 BP. Nevertheless, a small series of dates obtained from crust on fragments, demonstrates a more ancient age as compared with the main array of dates. The nature of such phenomenon currently not entirely clear .

Keywords: Early Neolithic; Upper Volga culture; the Volga-Oka region; radiocarbon dating

\section{УДК 902.2}

\section{НАЧАЛО РАСПРОСТРАНЕНИЯ ТЕХНОЛОГИИ ИЗГОТОВЛЕНИЯ ГЕОМЕТРИЧЕСКИХ МИКРОЛИТОВ «СО СТРУГАНЫМИ СПИНКАМИ»}

(C) 2014

B.A. Манько, кандидат исторических наук, старший научный сотрудник отдела археологии Крыма Институт археологии НАН Украины, Киев (Украина)

Аннотащия: Автор анализирует процесс появления и распространения геометрических микролитов с плоской отжимной дорсальной ретушью на территории Ближнего и Среднего Востока, в бассейне Восточного Средиземноморья и в Восточной Европе. Рассматривается типология указанных изделий, их роль в комплексах неолита Восточной Европы. На основе анализа типологии и технологии изготовления устанавливаются первичные и вторичные очаги распространения новой технологии.

Ключевые слова: неолит; отжимная техника расщепления; геометрические микролиты с дорсальной струйчатой ретушью; микролиты с «гелуанской» ретушью.

Появление и распространение специфических форм геометрических микролитов «со стругаными спинками» стали причиной такой ситуации на территории Восточной Европы, когда традиционный подход для культурной дифференциации различных феноменов, основанный на анализе комплексов геометрических микролитов, выявил существенные недостатки. Распространение геометрических микролитов, изготовленных даже с применением разных технологий, привело к распространению подобных типов, слабо различающихся по внешнему виду. В результате появились теории о конвергентном развитии неолитических культур, о стирании граней между различными культурами в неолите, об утрате информативности каменных индустрий для процедуры индикации культурных явлений. Так, Д.Ю. Нужный пишет об утрате типологического разнообразия геометрических микролитов [1, с.78].

Тем не менее, история распространения указанных специфических типов микролитов является важной для понимания культурно-исторических процессов на территории Восточной Европы. Хронология распространения явления очень ярко иллюстрирует процессы миграций, культурного обмена между населением как смежных, так и удаленных регионов, последовательность процессов вовлечения отдельных групп населения в систему распространения неолитических инноваций.
Для переосмысления многочисленных комплексов геометрических микролитов со «стругаными спинками» в качестве информативного археологического источника нам необходимо описать их типологическое многообразие, которое в реальности все же существует, выяснить историю формирования типа в каждом регионе. Только после этого, используя метод корреляции с данными абсолютной хронологии, мы сможем использовать данный тип изделий как полноценный источник для реконструкции культурно-исторического процесса.

Геометрический микролит со струганой спинкой - это изделие из пластинчатой заготовки, а именно - из медиальной части заготовки либо из целой пластины или пластинки, со струйчатой дорсальной ретушью, нанесенной отжимным способом. Для изготовления геометрических микролитов на территории Восточной Европы использовались пластинчатые заготовки, полученные исключительно отжимным способом. На территории Ближнего и Среднего Востока заготовками могли быть также пластины, полученные традиционным ударным методом. В комплексах Ближнего и Среднего Востока известны только трапеции и треугольники «со стругаными спинками», европейские комплексы демонстрируют большее типологическое разнообразие: включают также сегменты и ромбы.

Для построения типологии мы используем следующие 